\title{
Brood chamber isolation during salinity stress in two estuarine mollusk species: from a protective nursery to a dangerous prison
}

\author{
O. R. Chaparro ${ }^{1, *}$, C. J. Segura ${ }^{1}$, J. A. Montory ${ }^{1}$, J. M. Navarro ${ }^{1}$, J. A. Pechenik ${ }^{2}$ \\ ${ }^{1}$ Instituto de Biología Marina Dr. Jürgen Winter, Universidad Austral de Chile, Casilla 567, Valdivia, Chile \\ ${ }^{2}$ Biology Department, Tufts University, Medford, Massachusetts 02155, USA
}

\begin{abstract}
Faced with environmental stress, the females of many marine invertebrate species can isolate their brood chambers from the external environment for prolonged periods. Although brood chambers have therefore typically been assumed to protect the brooded embryos, the effects of continued isolation on conditions within brood chambers have not been examined. In the present research, we investigated the effects of external stress on conditions in the brood chambers for 2 sympatric species, the gastropod Crepipatella dilatata and the bivalve Ostrea chilensis. Both species incubate their embryos in the pallial cavity for at least $4 \mathrm{wk}$ before the young emerge as larvae (oyster) or juveniles (gastropod). Brooding and non-brooding females were stimulated to isolate the pallial cavity from the external environment by exposing them to water of reduced salinity $(<22$ to $24 \mathrm{psu}$ ). We then recorded subsequent changes in salinity, dissolved oxygen, $\mathrm{pH}$, and ammonium ion concentration within the pallial fluid. Although salinity within the pallial cavity remained high for both species, oxygen availability for brooding females of $C$. dilatata and $O$. chilensis dropped to hypoxic levels $\left(<1.5 \mathrm{mg} \mathrm{O}_{2} \mathrm{l}^{-1}\right)$ within $12 \mathrm{~h}$ and $20 \mathrm{~min}$, respectively. In addition, $\mathrm{pH}$ of the intrapallial fluid dropped substantially with prolonged maternal isolation, suggesting a possible impact on shell formation for brooded veligers. Indeed, in the case of $C$. dilatata, the $\mathrm{pH}$ of pallial fluid initially fell to 6.4, but then tended to become more basic after $6 \mathrm{~h}$ of maternal isolation, a possible consequence of shell dissolution. On the other hand, ammonium ion concentration increased progressively with prolonged maternal isolation. Our data show that, whereas initially the isolation mechanism protected incubated embryos from exposure to low salinity stress, continued isolation from the exterior transformed the brood cavity from a protective environment to an oppressive one, i.e. from a protective nursery to more of a prison.
\end{abstract}

KEY WORDS: Brooding · Brood chamber - Crepipatella dilatata · Estuary · Embryos · Ostrea chilensis $\cdot$ Pallial cavity $\cdot$ Salinity stress $\cdot$ Tidal cycles

\section{INTRODUCTION}

Protection of embryos can range in complexity from simply covering the embryos with a thin membrane or mucous in some species to incubation in sophisticated and specialized cavities in others (Thorson 1946, Mackie et al. 1974, Gallardo 1987). Such incubation by the female is generally considered to be protective (Gillespie \& McClintock 2007). Such physical maternal protection of the spawned egg mass is apparently an evolved, complex, and expensive mechanism (Chaparro \& Thompson 1998, Brante et al. 2003, Raymond et al. 2004). Retaining embryos and larvae in such enclosures reduces the predation risks to which they would be exposed during a pelagic larval phase (Pechenik 1978, Rumrill 1990) and can also isolate the offspring from physical stresses, as might be caused, for example, by substantial changes in humidity, $\mathrm{pH}$, dissolved oxygen, osmotic concentration, or salinity (see reviews by Clutton-Brock 1991, Morritt \& Spicer 1996, Surbida 
\& Wright 2001). In the particular case of estuaries, which are characterized by especially large fluctuations in salinity, incubation of embryos may be an essential mechanism for promoting embryonic survival in the face of fluctuating salinities produced during tidal cycles and periods of intense rain (Chaparro et al. 2008a). In such estuarine environments, changes in osmotic pressure could represent one of the major stressors for developmental stages (Kinne 1971). Maternal protection of embryos has been identified in such estuarine species as the oyster Ostrea chilensis (Chaparro et al. 1993), the clam Kingiella chilenica (Gallardo 1993), and the gastropod Crepipatella dilatata (Collin et al. 2007).

In the absence of maternal protection, encapsulated embryos can be subjected to both dehydration (Pechenik 1978, Rawlings 1999) and osmotic stress (Pechenik 1982, 1983) when the capsules are exposed to air or to pronounced salinity fluctuation, respectively. In contrast, females that brood their embryos should be able to isolate them from detrimental external conditions, enhancing embryonic survival during environmentally stressful periods: if females isolate their brood chambers just as environmental conditions begin to deteriorate, then the water retained in the pallial cavity or in the brood chamber of the incubating mothers should, at least initially, have appropriate characteristics to support embryonic development. In this sense, brood chambers can thus function as a sort of benign 'kindergarten' for the incubated offspring. Once environmental conditions improve (e.g. when external salinity increases during the flooding tide), females should sense that change and re-open the brood chamber to the external environment (Chaparro et al. 2008b).

Over prolonged periods of isolation, however, characteristics of the water retained in the pallial cavity or brood chamber may gradually change, a possibility that has previously been rarely considered. In particular, we hypothesized that 'protected' embryos will eventually experience reduced oxygen availability, increasing acidity of the surrounding fluid, and accumulation of metabolic wastes, each of which could harm development. The magnitude and rate of such deterioration have not been assessed previously.

The estuary of the Quempillén River, Chile, exhibits strong alterations in salinity due to tidal cycles and/or intense rains (Chaparro et al. 2008c). Salinities can drop to as low as 6 to 9 psu (Toro \& Winter 1983, Chaparro et al. 2008c). Sometimes salinity remained below 20 psu for 12 to $24 \mathrm{~h}$, and, on 1 occasion, for $>48 \mathrm{~h}$ (O. R. Chaparro pers. obs.). Such rapid, large, and prolonged salinity changes can occur during the reproductive periods of the 2 most abundant mollusk species in the estuary, the gastropod Crepipatella dilatata and the oyster Ostrea chilensis. Both species brood their embryos in the pallial cavity. The gastropod deposits developing embryos and nurse eggs in capsules, with numerous eggs per capsule. The capsules are firmly glued to hard substrate at the ends of their 'stalks,' and females retain the capsules under their shells for at least $4 \mathrm{wk}$ until juveniles emerge (Gallardo 1979). In contrast, O. chilensis incubates its embryos directly in the pallial cavity for about $8 \mathrm{wk}$, releasing veligers that can settle on appropriate substrate and begin metamorphosing almost immediately after their release (Toro \& Chaparro 1990, Chaparro et al. 1993, Videla et al. 1998).

Considering that incubation of embryos has always been considered to be beneficial to the incubated embryos, in the present research we documented the changes that take place in the microenvironment of the brood cavity when mothers isolate that chamber from the environment, monitoring changes in salinity, dissolved oxygen, $\mathrm{pH}$, and ammonium. How rapidly will the isolated brood chamber change from being a supportive 'nursery' to being more of a 'juvenile jail'?

\section{MATERIALS AND METHODS}

Adults of the gastropod Crepipatella dilatata and the bivalve Ostrea chilensis were collected from the subtidal area of the Quempillén estuary $\left(41^{\circ} 52^{\prime} \mathrm{S}\right.$, $73^{\circ} 46^{\prime} \mathrm{W}$ ), south of Chile and brought to the laboratory.

Specimens of Crepipatella dilatata $(2.5$ to $3.5 \mathrm{~cm}$ shell length) were carefully removed from the original substrates to which they had been attached. In the laboratory, they were then individually placed on transparent acrylic plates $(200 \times 300$ and $2 \mathrm{~mm}$ thick $)$, allowing us to later determine which individuals were brooding and the stage of development that the brooded embryos were at, and maintained in aquaria with circulating water taken directly from the estuary. The mollusks were maintained in the laboratory for several days, until they had adhered firmly to the acrylic plates. Approximately 1 wk later, the acrylic plates and their associated snails were returned to the original collection site in the estuary, where they remained for the next 2 to 3 mo. Many of them produced egg masses during that time, allowing us to conduct experiments using both brooding and nonbrooding specimens. Females included in our experiments were generally brooding embryos at approximately the same stage of development and size (about 500 to $700 \mu \mathrm{m}$ shell length).

Adult specimens of the oyster Ostrea chilensis (4 to $6 \mathrm{~cm}$ in shell length) were collected 2 to 3 mo before 
the beginning of reproduction (brooding). Individuals with shells in this size range are likely to reproduce as females (Wilson et al. 1996). A small hole of approximately 2 to $3 \mathrm{~mm}$ diameter was made in the lateral right sector of the superior shell valve of each individual. Later, the specimens were returned to the estuary and maintained suspended in a floating net system for 3 to $4 \mathrm{mo}$, during which time the perforation in the shell became covered by new shell material and many of the females began the incubation process.

A few days before the experiments, specimens of Crepipatella dilatata attached to the acrylic plates were taken to the laboratory and kept in aquaria with circulating water taken directly from the estuary. Small holes (2 to $3 \mathrm{~mm}$ diameter) were drilled into the plates just above the brood chamber of each specimen. A stem was then inserted through each hole, allowing us to directly access the water in the brood cavity during experiments. During experiments, the plates were maintained in aquaria, with the drilled surface facing upwards and with the distal end of the stem projecting upwards into the air. This was done to facilitate access to water samples from the pallial cavities and to prevent aquarium water from entering brood chambers during the isolation period.

Determining threshold salinity for brood chamber isolation. Brooding and non-brooding specimens of Crepipatella dilatata and Ostrea chilensis were maintained in aquaria with an initial salinity of $30 \mathrm{psu}$, equivalent to estuarine salinity at high tide. For each species, salinity in aquaria was gradually reduced by adding distilled water at a rate designed to match what occurs naturally during tidal cycles in the Quempillén estuary. The water in each aquarium was agitated periodically to avoid local areas of reduced salinity. Final salinity in all aquaria was 5 psu.

Salinity in the pallial cavity of brooding and nonbrooding specimens was determined when ambient salinities in the surrounding water were 30, 25, 20, 15, 10 , and 5 psu. Salinity within brood chambers in the space surrounding the egg capsules (Crepipatella dilatata) or embryos (Ostrea chilensis) was sampled using $2 \mathrm{~mm}$ diameter electrodes (Microelectrodes). For C. dilatata, measurements were made repeatedly on the same group of individuals. For $O$. chilensis, a different group of 10 individuals was sampled at each time point, because samples could be taken only by breaking through the newly secreted shell material in order to access the original drill hole and insert the sensor into the pallial cavity; it was not possible to reuse the same individuals because the open hole would allow seawater to enter from the exterior into the pallial cavity.
By determining the threshold salinity causing females to isolate their brooded embryos from the environment, we could provoke the isolation of brood chambers in subsequent experiments at will.

Effect of isolation by low salinity on intrapallial chamber salinity. For a group of specimens of Crepipatella dilatata, prepared as described above, the salinity in the aquarium was gradually reduced to $10 \mathrm{psu}$ to induce females to isolate the brood chamber from the exterior. From that moment and hourly for the next $12 \mathrm{~h}$, the salinity of the water retained in the pallial cavity of brooding and non-brooding specimens was monitored to see how well isolation maintained the original salinity over time. Controls were established as previously described.

Comparable studies were conducted in the laboratory for a group of oysters, gradually reducing external salinity to $10 \mathrm{psu}$ to force valve closure. Salinity in the pallial cavity was recorded at intervals over the next $12 \mathrm{~h}$, using a different group of 10 individuals for each time point sampled.

Effect of isolation on oxygen concentration. Adults of Crepipatella dilatata attached to transparent acrylic plates were returned to the laboratory. Before conducting the experiments, holes of approximately $2 \mathrm{~mm}$ diameter were drilled into the reverse side of the acrylic plates, just behind the brood chamber of each brooding or non-brooding female. Oxygen determinations were made using a precision sensing Microx TX3 oxygen meter (PreSens). Oxygen sensors were installed inside blunt needles, which allowed us to access the pallial cavity of experimental animals through the small holes made in the acrylic plates. Sensors occupied the same general space - the area surrounding the egg capsules - for each individual, and did not penetrate the capsules themselves. To prevent water entering from the exterior, we attached a non-toxic silicone pad to the base of the needle containing the oxygen sensor. The edges of the needle were sealed to the acrylic plates using a plug of nontoxic silicone. The oxygen meter was calibrated at $12^{\circ} \mathrm{C}$ with a saturated solution of $\mathrm{Na}_{2} \mathrm{SO}_{3}(0 \%$ oxygen saturation) and with thoroughly aerated distilled water (100\% saturation).

Before inserting the sensor inside the pallial cavity, the experimental specimens were maintained in aquaria in full-strength seawater (30 psu) for several hours, at constant temperature $\left(12^{\circ} \mathrm{C}\right)$ and with vigorous aeration, allowing them to open up to the exterior and begin normal water circulation activities. After inserting the electrodes, we waited until individuals resumed their filtering activity before making our first oxygen determination. The salinity of water in the aquaria was then rapidly reduced to as low as $10 \mathrm{psu}$, provoking valve closure and brood chamber isolation. 
Thereafter, oxygen concentration inside the brood cavity was monitored continuously until conditions became hypoxic $\left(<1.5 \mathrm{mg} \mathrm{O}_{2} \mathrm{l}^{-1}\right)$ or anoxic $\left(<0.08 \mathrm{mg} \mathrm{O}_{2}\right.$ $\mathrm{l}^{-1}$ ) (sensu Baker \& Mann 1992, Tankersley \& Wieber 2000).

Once conditions in the pallial cavity of Crepipatella dilatata became anoxic, the salinity in aquaria was gradually increased by 2.5 psu every $30 \mathrm{~min}$, to determine the salinity at which the mothers would resume exchanging water with the exterior.

For the oyster Ostrea chilensis, brooding and nonbrooding specimens were taken from the estuary to the laboratory and established in aquaria at $30 \mathrm{psu}$. The new shell material that had been deposited over the hole in the shell of each specimen was removed and a short piece of $2 \mathrm{~mm}$ diameter tubing was inserted. The specimens were maintained in the aquaria completely submerged except for the tip of the tubing, which was exposed to the air above the level of the water, thus preventing seawater from entering the oyster's pallial cavity. An optic sensor connected to an oxygen meter was inserted through the tubing. Once individuals resumed their pumping activity, we began measuring the oxygen content inside the pallial cavity. After that, oysters were forced to isolate their brood chambers from the exterior seawater, and were then maintained in that condition until the brood chamber became hypoxic $\left(<1.5 \mathrm{mg} \mathrm{O} \mathrm{O}^{-1}\right)$ or anoxic $(<0.08 \mathrm{mg}$ $\mathrm{O}_{2} \mathrm{l}^{-1}$ ) as previously described.

The oxygen sensors were connected to a computer system that allowed the continuous documentation of oxygen content. The oxygen sensor covered by a blunt needle was introduced by the stem reaching directly to the interdemibranchial region of brooding and nonbrooding specimens. Specimens were always maintained at a constant temperature of $12^{\circ} \mathrm{C}$ during experiments to avoid fluctuations of oxygen that would be caused by temperature-related changes in solubility.

Effect of isolation on pH. A set of specimens of Crepipatella dilatata attached to transparent acrylic plates (as described previously) were installed in aquaria filled with circulating estuarine water (30 psu). After the females were circulating water normally, the first $\mathrm{pH}$ measurements were made by simultaneously sampling water from the aquaria and from the pallial cavity. The flow of water into the aquaria was then stopped, and the salinity of the remaining water was reduced rapidly to $10 \mathrm{psu}$, forcing the gastropods to isolate themselves from the surrounding seawater. Measurements of $\mathrm{pH}$ were then made every hour for $12 \mathrm{~h}$. These measurements were made by inserting a pH sensor (Microelectrodes) of $1.6 \mathrm{~mm}$ diameter through tubing that allowed access to the pallial cavity fluid of brooding and nonbrooding individuals. Again, the sensors were placed in approximately the same position for all individuals sampled.

Brooding and non-brooding specimens of Ostrea chilensis were transferred to the laboratory from the estuary and kept in aquaria at 30 psu salinity. After the oysters opened their shells and resumed circulating water through their mantle cavities, $\mathrm{pH}$ was determined in the surrounding water and then internally for a group of 10 oysters. Immediately, the aquarium salinity was reduced to $10 \mathrm{psu}$, forcing the oysters to close their shell valves and isolate themselves from the surrounding water. Each hour for the following $12 \mathrm{~h}$, the $\mathrm{pH}$ in the pallial cavity of the oysters was recorded. As explained previously, a new group of 10 individuals was sampled at each time point.

Effect of isolation on ammonium concentration. Ammonium was determined in specimens of Crepipatella dilatata and Ostrea chilensis obtained from the Quempillén estuary, using the Solorzano method (Solorzano 1969). At the beginning of the experiments, ammonium-nitrogen values were quantified in both the water of the aquaria (obtained from the estuary at high tide) and in the pallial cavity of both mollusk species. Water flow was then stopped and aquarium salinity was reduced to $10 \mathrm{psu}$, forcing the specimens to close their shell valves and isolate themselves from the surrounding environment. Each hour for the following $12 \mathrm{~h}$, ammonium content in the pallial cavity water was determined for both brooding and non-brooding specimens. A different group of individuals was sampled at each time point $(\mathrm{n}=4$ brooding females, $\mathrm{n}=5$ nonbrooding females) due to the small volume of water available in the pallial cavity of the animals.

Immediately after the extraction of the intrapallial water from the gastropod and the oyster, samples were centrifuged for $10 \mathrm{~min}$ at $1000 \mathrm{rpm}$ to pellet out the mucous coming from the pallial cavity and then were treated according to Solorzano (Solorzano 1969) to determine ammonium content.

Statistical analysis. Normality and homogeneity of variance of the data were first determined. Then, repeated-measures analysis of variance (ANOVA) was used to identify differences in salinity, $\mathrm{pH}$, and oxygen in the pallial cavity of Crepipatella dilatata and oxygen in Ostrea chilensis over time and between brooding and non-brooding specimens. Two-way ANOVA was used to identify possible differences of ammonium in C. dilatata and salinity, $\mathrm{pH}$, and ammonium in $O$. chilensis over time and between brooding and non-brooding specimens; an a posteriori Tukey test was used when significant differences were found. When the data were heterogeneous, they were normalized by square-root transformation or using the reciprocal of the value (Underwood 1997) before further analysis. 


\section{RESULTS}

\section{Effect of isolation on salinity}

For Crepipatella dilatata at salinities of 30 and $25 \mathrm{psu}$, salinity in the pallial cavity of the gastropods did not differ significantly from that of the surrounding seawater (Fig. 1A). As external salinity continued to decline, however, mean salinity in the pallial cavity never fell below about 24 psu (Fig. 1A), implying that females had sealed themselves against the substrate and ceased circulating water through the brood chamber. The environmental salinity inducing such isolation did not differ significantly between brooding and non-brooding specimens (repeated-measures ANOVA, $\left.F_{1,98}=0.5, \mathrm{p}=0.508\right)$. The salinity of the fluid retained in the pallial cavity remained nearly
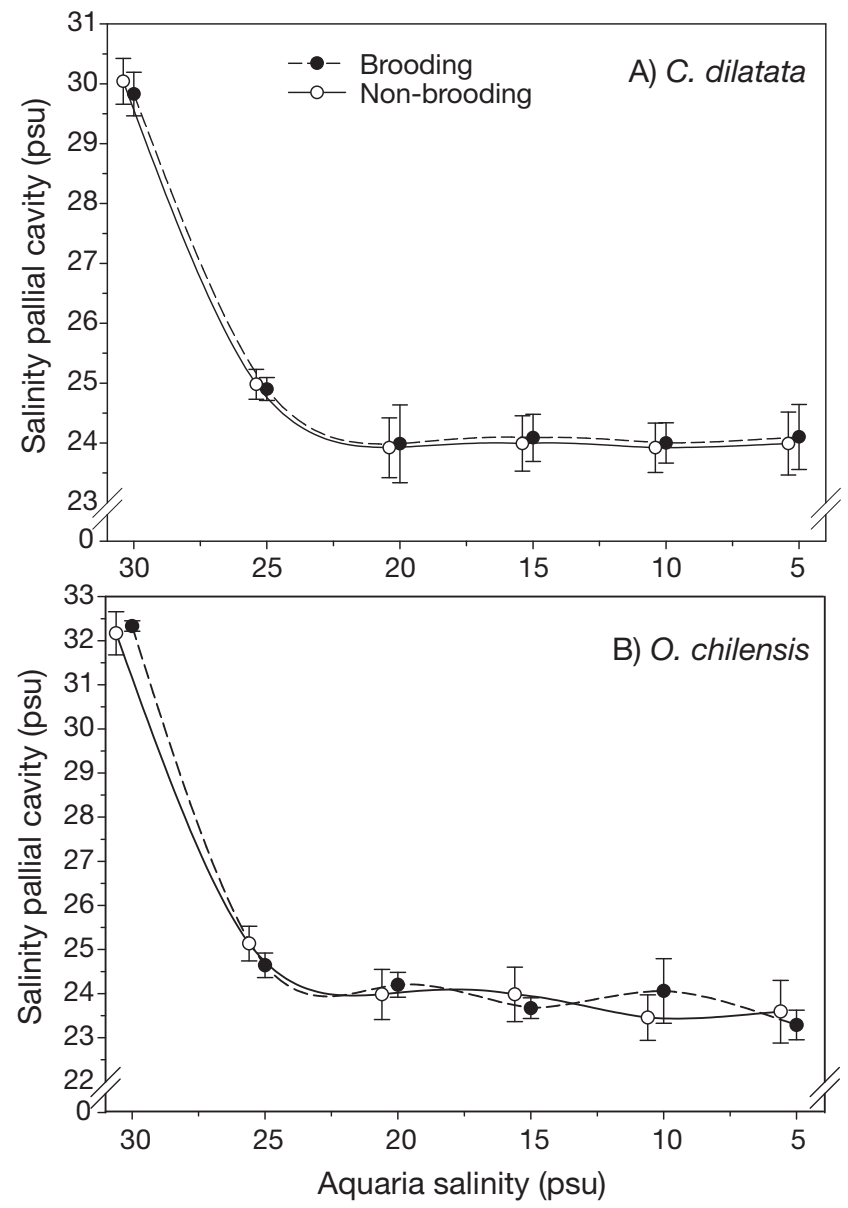

Fig. 1. Crepipatella dilatata and Ostrea chilensis. Effects of reduced salinity on valve closure and brood chamber salinity in brooding and non-brooding females. Each point represents the mean and $\mathrm{SD}$ (total $\mathrm{n}=120$ measurements for limpets and 120 measurements for oysters), with 10 replicates per salinity value
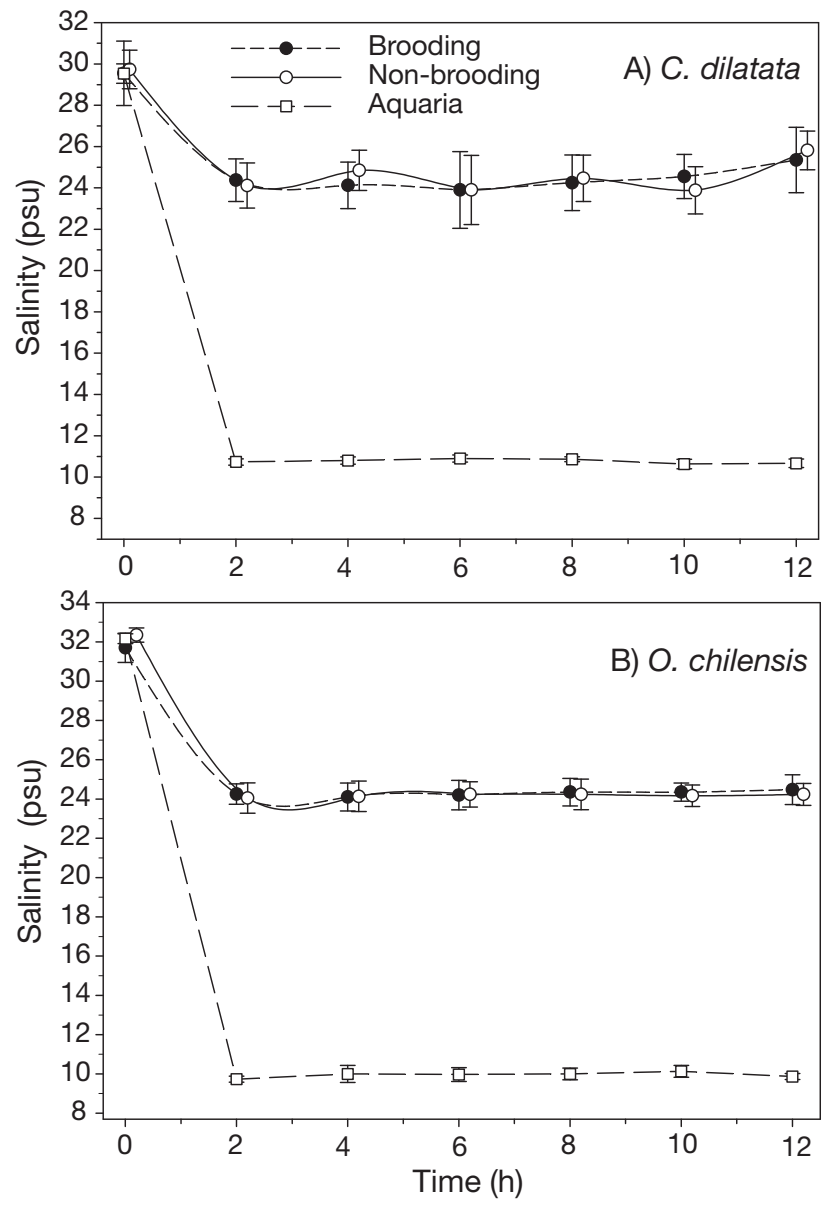

Fig. 2. Crepipatella dilatata and Ostrea chilensis. Mean salinity in the pallial cavity over time for brooding and non-brooding specimens after females isolated their brood chambers in response to reduced ambient salinity. $\square$ : salinity surrounding the mollusks in the aquaria. Each point represents the mean and SD (total $n=98$ measurements for limpets; total $n=91$ measurements for oysters), with 6 to 7 replicates for each time point

constant (approximately 22 to $25 \mathrm{psu}$ ) over the next 2 to $12 \mathrm{~h}$ following isolation (Fig. 2A) for both brooding and non-brooding females (repeated-measures ANOVA, $F_{1,98}=0.4, \mathrm{p}=0.878$ ) even when external salinity was only $10 \mathrm{psu}$.

For the oyster Ostrea chilensis, individuals closed their valves when external salinity dropped to about $24 \mathrm{psu}$, at which time internal and external salinities were identical. The salinity of the water retained in the pallial cavity did not differ significantly between brooding and non-brooding oysters (Fig. 1B) (2-way ANOVA, $\left.F_{1,120}=0.4, \mathrm{p}=0.55\right)$. The salinity of water retained in the pallial cavity remained at approximately 24 psu over the subsequent $12 \mathrm{~h}$ of isolation for both brooding and non-brooding specimens (Fig. 2B) (2-way ANOVA, $F_{6,91}=0.52, \mathrm{p}=0.79$ ). 


\section{Effect of isolation on oxygen within the brood chamber}

For Crepipatella dilatata, dissolved oxygen in the pallial cavity before isolation from the exterior showed maximum average values of $8.2 \mathrm{mg} \mathrm{l}^{-1}$, close to the saturation level of seawater in the aquaria. Oxygen concentration in the pallial cavity decreased significantly with time (repeated-measures ANOVA, $F_{30,465}=2.9, \mathrm{p}=0.0001$ ) in both brooding and nonbrooding females (Fig. 3A). The degree to which oxygen declined differed, however, between brooding and non-brooding specimens within $9 \mathrm{~h}$ of isolation (repeated-measures ANOVA, $F_{1,465}=12.9, \mathrm{p}=0.002$ ) (Fig. 3A): although both brooding and non-brooding females exhibited continuous oxygen consumption, the mantle cavity fluid of brooding specimens reached hypoxic levels (mean concentration <1.5 $\mathrm{mg} \mathrm{O}_{2} \mathrm{l}^{-1}$ ) within $12 \mathrm{~h}$ of isolation, while non-brooding females still showed normoxic conditions at that time, with
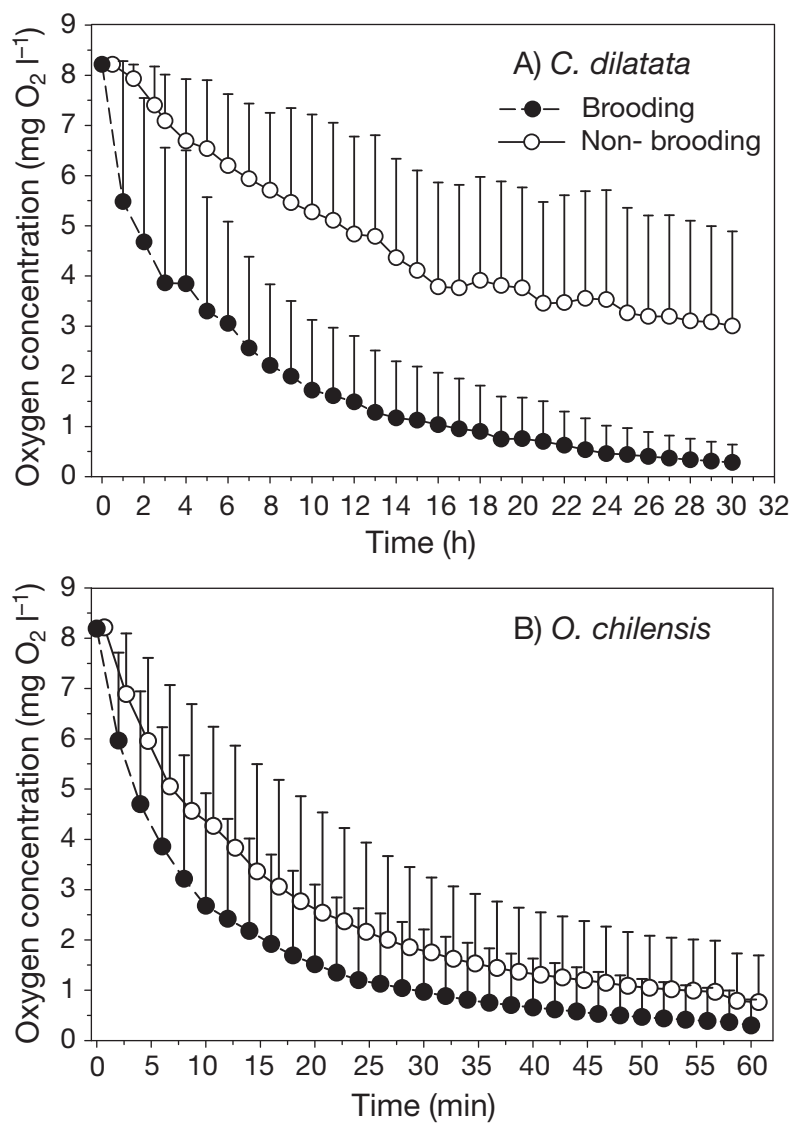

Fig. 3. Crepipatella dilatata and Ostrea chilensis. Dissolved oxygen content in the water retained in the pallial cavity during isolation by brooding and non-brooding females. Each point represents the mean and SD (total $n=465$ measurements for limpets; total $\mathrm{n}=1098$ measurements for oysters), with 7 to 17 replicates for each time point. Note the different time scales mean values of approximately $4.7 \mathrm{mg} \mathrm{O}_{2} \mathrm{l}^{-1}$. Even after $30 \mathrm{~h}$ of isolation from the exterior, while brooding females showed extreme hypoxia $\left(0.2 \mathrm{mg} \mathrm{O}_{2} \mathrm{l}^{-1}\right)$, nonbrooding females still maintained only suboxic conditions (2.9 $\mathrm{mg} \mathrm{O}_{2} \mathrm{l}^{-1}$ ) in the brood chamber (Fig. 3A).

For the oyster Ostrea chilensis, the oxygen concentration detected in actively pumping oysters was approximately $8.2 \mathrm{mg} \mathrm{O}_{2} \mathrm{l}^{-1}$, similar to values detected in the surrounding aquarium water. Remarkably, the oxygen concentration inside the brood chambers began to decline significantly (repeated-measures ANOVA, $F_{60,1098}=86.6, \mathrm{p}=0.0001$ ) only $4 \mathrm{~min}$ after the valves closed in both brooding and non-brooding females. Oxygen in the pallial cavity continued to decline rapidly over the next $30 \mathrm{~min}$ for both sets of females (Fig. 3B). Brooding females were only incubating early (morula-blastula stage) embryos during our study, with low rates of embryonic oxygen consumption. The oxygen content in the pallial cavity of brooding and non-brooding individuals showed no significant differences (repeated-measures ANOVA, $\left.F_{1,1098}=1.1, \mathrm{p}=0.3\right)$.

As external salinity was gradually restored to that of full-strength seawater (30 psu), the oxygen concentration of fluid in the pallial cavity of the gastropod Crepipatella dilatata also increased. However, brooding and non-brooding females showed different behaviors (2way ANOVA, $F_{6,98}=7.5, \mathrm{p}=0.0001$ ), with brooding individuals beginning to replace water in the mantle cavity when salinity reached approximately 20 psu. Non-brooding females did not evidence any watertesting behavior or circulation activity until salinities rose to approximately 25 psu (Fig. 4).

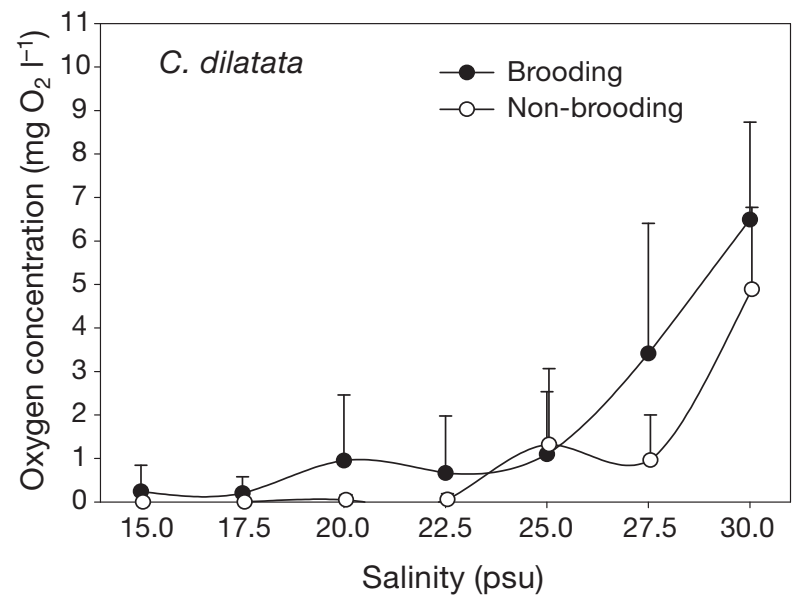

Fig. 4. Crepipatella dilatata. Changes in dissolved oxygen in the pallial cavity as ambient salinity increased in brooding and non-brooding females. Each point represents the mean and SD ( $\mathrm{n}=98$ measurements in total; 7 replicates per sampling point) 


\section{Effect of isolation on $\mathrm{pH}$}

In the gastropod Crepipatella dilatata, $\mathrm{pH}$ of the pallial fluid decreased significantly while the pallial cavity was isolated from the surrounding environment (Fig. 5A) (repeated-measures ANOVA, $F_{12,140}=2.1, \mathrm{p}=$ 0.0247 ). In brooding specimens the initial average $\mathrm{pH}$ was 7.5. By the fourth hour of isolation, however, $\mathrm{pH}$ had declined to 6.5 ( $\mathrm{SD}=0.05)$, and average $\mathrm{pH}$ remained more or less constant over the next $8 \mathrm{~h}$, with a final value of $6.7(\mathrm{SD}=0.11)$ at the end of $12 \mathrm{~h}$. In non-brooding specimens the initial average $\mathrm{pH}$ was 7.7. By the fifth hour of isolation the average $\mathrm{pH}$ of the pallial cavity fluid had fallen to $6.4(\mathrm{SD}=0.08)$, and it remained at approximately that level during the next $7 \mathrm{~h}$ of isolation. As with brooding individuals, the final
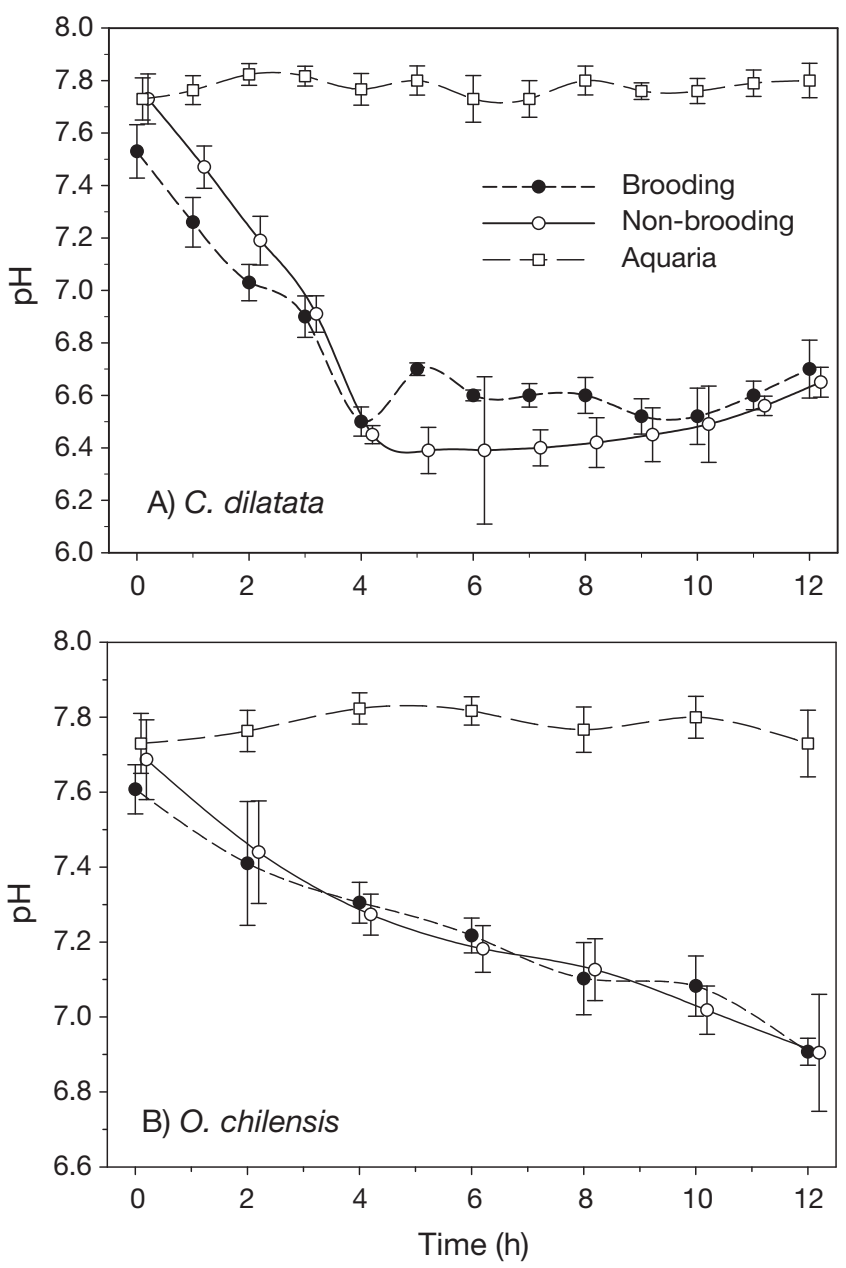

Fig. 5. Crepipatella dilatata and Ostrea chilensis. $\mathrm{pH}$ values of water in aquaria and in the pallial cavity during periods of isolation in brooding and non-brooding females. Each point represents the mean and SD (total $n=140$ measurements for limpets; total $\mathrm{n}=91$ measurements for oysters), with 5 to 7 replicates for each time point
pH was $6.7(\mathrm{SD}=0.05)$ at $12 \mathrm{~h}$ (Fig. 5A). The pattern of $\mathrm{pH}$ in the pallial fluid was not significantly different for brooding and non-brooding individuals (repeatedmeasures ANOVA, $F_{1,140}=3.0, \mathrm{p}=0.131$ ).

The $\mathrm{pH}$ of water in aquaria did not vary significantly over time during these experiments $\left(F_{6,39}=0.9, \mathrm{p}=\right.$ 0.586).

For the oyster Ostrea chilensis, internal $\mathrm{pH}$ also diminished significantly over time while the pallial cavity was isolated from the external environment (Fig. 5B) (2-way ANOVA, $F_{6,91}=42, \mathrm{p}=0.0001$ ). In both brooding and non-brooding specimens, the average initial $\mathrm{pH}$ of $7.6(\mathrm{SD}=0.06)$ and $7.7(\mathrm{SD}=0.1)$, respectively, declined to final average values of 6.9 $(\mathrm{SD}=0.03)$ and $6.9(\mathrm{SD}=0.1)$, respectively (Fig. 5B).

As before, the $\mathrm{pH}$ of the surrounding water in the aquaria did not change $\left(F_{6,21}=1.2, \mathrm{p}=0.384\right)$ during this time.

\section{Effect of isolation on ammonium concentration}

For both Crepipatella dilatata and Ostrea chilensis, conditions of reduced ambient salinity generated a significant increase (2-way ANOVA: $F_{12,117}=28.145$, $\mathrm{p}=0.0001 ; F_{12,104}=7.36, \mathrm{p}=0.0001$, respectively) in internal ammonium nitrogen levels during the $12 \mathrm{~h}$ of pallial cavity isolation. For the limpets, ammonia levels increased $>100 \%$ for both brooding and non-brooding individuals (Fig. 6A). For oysters, ammonium increased approximately $20 \%$ in both brooding and nonbrooding individuals, with no significant effect of brooding on final levels at the end of $12 \mathrm{~h}$ (Fig. 6B).

\section{DISCUSSION}

Incubation has traditionally been thought of as beneficial for the incubated embryos (e.g. Grant 1983, Fernández et al. 2000, Taborsky \& Foerster 2004, Monteiro et al. 2005); indeed, it is generally referred to as 'brood protection' (e.g. Thorson 1950). Maternal protection should reduce developmental mortality by isolating embryos from temporary external stresses (Clutton-Brock 1991). Among invertebrates, incubation takes many forms (e.g. inside the pallial cavity either anchored to branchial filaments as in Kingiella chilenica [Gallardo 1993] or free-swimming as in Ostrea chilensis [Chaparro et al. 1993]; in the water tubes of the outer demibranchs as in Anodonta cataracta [Tankersley \& Dimock 1992]; in capsules attached to the substrate and kept under the maternal shell Calyptreidae [Collin 2003]; in a gelatinous egg string retained underneath the outer mantle as in Protancylus [Albrecht \& Glaubrecht 2006]; retained in a pouch 

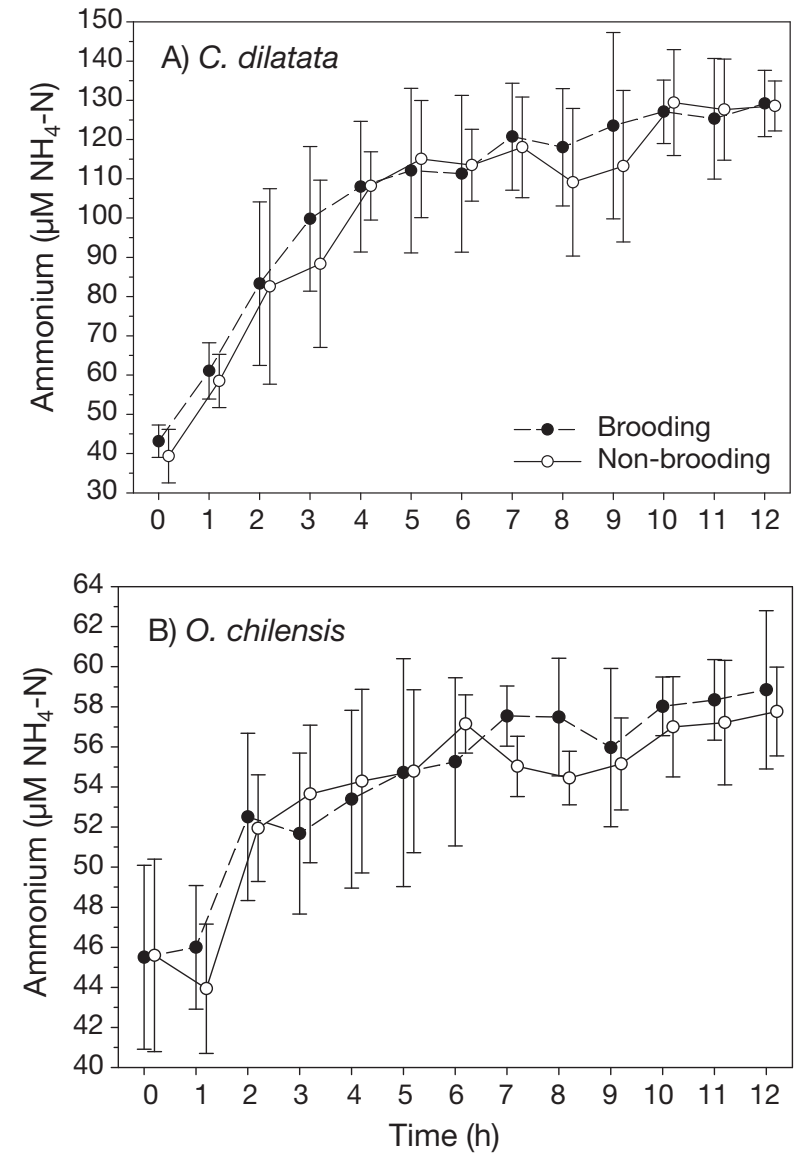

Fig. 6. Crepipatella dilatata and Ostrea chilensis. Changes in ammonium-nitrogen content in the water retained in the pallial cavity during brood chamber isolation by brooding and non-brooding females. Each point represents the mean and $\mathrm{SD}$ (total $\mathrm{n}=117$ measurements for limpets; total $\mathrm{n}=104$ measurements for oysters), with 4 to 5 replicates per time point

located in the anterodorsal region of the head-foot as in Melanoides tuberculata [Ben-Ami \& Hodgson 2005]; or incubated within a specialized marsupium as in Orchestia gammarellus [Morritt \& Spicer 1996]). Common to all of these situations is that the mother has a degree of control over the local environment to promote successful embryonic development (Morritt \& Spicer 1996, Surbida \& Wright 2001). In other cases, incubation may allow the mother to transfer nutritious material or inorganic elements to her offspring (e.g. Purchon 1968, Wood 1974, Morton 1977, Bartlett 1979, Tankersley \& Dimock 1992), and may also protect developmental stages from predation (Thorson 1950, Pechenik 1979).

Under certain conditions, brooding may also protect embryos from exposure to the sorts of temporary environmental changes that characterize estuaries. Salinity, in particular, has been called an 'ecological master factor' in estuaries (Kinne 1966), something that can regulate physiological processes and the behavior of the organisms that develop there (Navarro 1988, Hutchinson \& Hawkins 1992, Navarro \& Gonzalez 1998, Kim et al. 2001, Spicer \& Strömberg 2003, Marsden 2004). In the case of mollusks, isolating the pallial cavity from the exterior by valve closure (e.g. bivalve: Choromytilus chorus, Navarro 1988; Crassostrea virginica, Hand \& Stickle 1977; Mytilus edulis, Crassostrea gigas, Scrobicularia plana, Cardium edule, Mercenaria mercenaria, Modiolus modiolus, Shumway 1977; Anadara senilis, Djangmah et al. 1979) or, as in the case of gastropods, by adhering tightly to the substrate with the foot and simultaneously pressing the mantle against that substrate, is the most common response to low salinity stress (e.g. Fretter 1984, Crepipatella: Chaparro et al. 2008b). In our studies with $C$. dilatata and Ostrea chilensis, salinities of $<22$ to $25 \mathrm{psu}$ and of $<24 \mathrm{psu}$, respectively, caused adults to isolate themselves from the surrounding environment. Such salinity levels - and lower-are common at our study site in the Quempillén estuary during low tide in winter or during strong rains in other periods of the year, and, as mentioned earlier, can last for $>48 \mathrm{~h}(\mathrm{O}$. R. Chaparro pers. obs.).

For both the gastropod and the oyster included in the present study, salinity in the brood chambers remained quite high even during long periods of female isolation when external salinities were as low as 10 psu. Thus, as long as the mothers can isolate themselves from the exterior before external salinity falls to detrimental levels, and re-open as soon as external salinities return to safe levels, brooding does indeed protect the incubated embryos from osmotic stress (Chaparro et al. 2008a). However, our work shows that what would seem to be a protective 'kindergarten' environment for embryos under such conditions can quickly become a stressful environment for embryos, exposing them to substantial declines in both oxygen and $\mathrm{pH}$, and to increases in ammonium concentration.

When brooding females of Crepipatella dilatata were isolated from the external environment, the dissolved oxygen level in the intrapallial water fell dramatically, declining about $50 \%$ within about $3 \mathrm{~h}$ and reaching hypoxic levels within $12 \mathrm{~h}$. Non-brooding females maintained comparatively better oxygen conditions in the brood chamber, suggesting that the more rapid decline in oxygen for brooding females was due to embryonic activities: movement of embryos inside capsules and nurse egg consumption by the brooded embryos (Chaparro \& Paschke 1990). Brooding females might also actively move egg capsules about to facilitate diffusion of oxygen to embryos, or might actively clean the walls of egg capsules using the radula. At present, it is therefore uncertain as to how much of the more rapid oxygen decline seen in the 
pallial cavity of brooding females is caused by parental behavior and how much is caused by metabolic activity of the embryos themselves.

Brooding females began circulating water through the mantle cavity again when the external salinity rose to around $20 \mathrm{psu}$. In contrast, non-brooding females did not begin filtering water again until the salinity reached values near 25 psu, suggesting a behavioral adjustment by brooding females favoring embryonic development. In both cases, oxygen levels in the pallial water recovered quickly once water circulation was reinstituted by females. This cycle of oxygen availability in the pallial cavity is corroborated by Chaparro et al. (2008a), verifying that females can detect a salinity of around $22 \mathrm{psu}$ and then open or close the shell valves (and resume or cease filtering water) in response to a rising or falling tide, respectively.

In Ostrea chilensis, dissolved oxygen in the pallial cavity declined even more rapidly with valve closure. Brooding and non-brooding females showed no differences in rates of oxygen consumption when they were brooding early stages (morula-blastula stage), confirming results of an earlier study by Chaparro \& Thompson (1998). Presumably, higher rates of oxygen consumption will be recorded for females brooding embryos at more advanced stages of development than those tested in the present experiments, due to their greater per-embryo biomass and levels of activity.

Assuming that embryos survive prolonged periods of isolation from the exterior, something that requires checking in the future, our results suggest that brooded embryos may be able to activate anaerobic metabolic pathways under such a condition. Additional studies are needed to document the extent of survival and to understand the mechanisms used by each species to withstand periods of oxygen deficit while brooding.

Even if embryos can survive hypoxic conditions using anaerobic metabolic pathways, shell development may still be compromised: oxygen deficit has been shown to impede shell calcification in encapsulated veligers of the gastropod Chorus giganteus (Cancino et al. 2000). The impact of hypoxic conditions on embryonic shell calcification has not yet been examined for Ostrea chilensis or Crepipatella dilatata.

Equally problematic for embryos is the tendency for the pallial fluid to become substantially acidic during prolonged periods of isolation. Such acidification probably results from respiratory $\mathrm{CO}_{2}$ production along with the generation of terminal products of anaerobic metabolic pathways by the females and by the brooded embryos (Maeda-Martínez 1987). In Crepipatella dilatata, $\mathrm{pH}$ of the pallial fluid declined only during the first 4 to $5 \mathrm{~h}$ of isolation, suggesting the existence of a neutralization mechanism, probably related to the dissolution of calcareous shell material (Akberali 1980, Chapman et al. 1982, Maeda-Martínez 1987, Pennington \& Hadfield 1989, Cancino et al. 2003); both the shell valves of the females and the shells of the brooded veligers could be affected. The effects of reduced $\mathrm{pH}$ on embryonic shell structure and mineral composition and on embryonic shell growth is considered in a companion paper (Montory et al. 2009, this volume). In the case of Ostrea chilensis, $\mathrm{pH}$ of the pallial fluid declined constantly, but did not quite fall below neutral conditions even after $12 \mathrm{~h}$ of isolation (Fig. 5B). However, even this degree of $\mathrm{pH}$ decline could impact development of the veliger protoconch, since the relatively slow decrease of $\mathrm{pH}$ could reflect a simultaneous neutralization effect of calcium dissolving from protoconchs, something that could be examined in future studies.

Mollusks generate ammonium nitrogen as the main end product of protein metabolism (Bayne \& Newell 1983); ammonia nitrogen is highly soluble and very toxic (Harris et al. 1998). The production of this metabolite is not detrimental under normal conditions, as it is quickly diluted by surrounding seawater. However, the forced confinement of embryos inside an isolated brood chamber will lead to the accumulation of toxic elements, and so could have enormous repercussions on the fitness of incubated embryos.

In summary, the isolation of brood chambers brought about by low salinity successfully protected incubated embryos from exposure to those salinities for both the limpet Crepipatella dilatata and the oyster Ostrea chilensis. However, we have shown here that declining oxygen and $\mathrm{pH}$, and increasing levels of ammonium, gradually transform the brood chamber from a protective 'kindergarten' environment to more of a 'jail,' with as yet largely unknown consequences for the incubated embryos. Future work will determine the impact of such conditions on embryonic development and also consider the delayed impact that such exposure might have on juveniles and adults (i.e. the degree to which there are 'latent effects' resulting from such exposure, as reviewed by Pechenik 2006).

Acknowledgements. This research was supported by FONDECYT-Chile Grant No. 1060194 to O.R.C.

\section{LITERATURE CITED}

Akberali HB (1980) ${ }^{45}$ Calcium uptake and dissolution in the shell of Scrobicularia plana (da Costa). J Exp Mar Biol Ecol 43:1-9

Albrecht C, Glaubrecht M (2006) Brood care among basommatophorans: a unique reproductive strategy in the freshwater limpet snail Protancylus (Heterobranchia: Protancylidae), endemic to ancient lakes on Sulawesi, Indonesia. Acta Zool 87:49-58 
Baker SM, Mann R (1992) Effects of hypoxia and anoxia on larval settlement, juvenile growth, and juvenile survival of the oyster Crassostrea virginica. Biol Bull 182:265-269

Bartlett BR (1979) The possible role of gill filament papillae in the development of the brooding bivalve, Parastarte triquetra. Am Zool 19:957

Bayne BL, Newell RC (1983) Physiological energetics of marine molluscs. In: Saleuddin ASM, Wilbur KM (eds) The Mollusca, Vol 4. Physiology, Part 1. Academic Press, New York, p 407-523

Ben-Ami F, Hodgson AN (2005) Ovoviviparity and the structure of the brood pouch in Melanoides tuberculata (Gastropoda: Prosobranchia: Thiaridae). J Morphol 263: 322-329

Brante A, Fernández M, Eckerle L, Mark F, Pörtner HO, Arntz W (2003) Reproductive investment in the crab Cancer setosus along a latitudinal cline: egg production, embryo losses and embryo ventilation. Mar Ecol Prog Ser 251: 221-232

- Cancino JM, Gallardo JA, Torres F, Leiva G, Navarro JM (2000) Effects of sessile protozoa on intracapsular oxygen tension and embryonic shell calcification in the muricid Chorus giganteus. Mar Ecol Prog Ser 200:141-148

Cancino JM, Gallardo JA, Torres FA (2003) Combined effects of dissolved oxygen concentration and water temperature on embryonic development and larval shell secretion in the marine snail Chorus giganteus (Gastropoda: Muricidae). Mar Biol 142:133-139

> Chaparro OR, Paschke KA (1990) Nurse egg feeding and energy balance in embryos of Crepidula dilatata (Gastropoda: Calyptraeidae) during intracapsular development. Mar Ecol Prog Ser 65:183-191

Chaparro OR, Thompson RJ (1998) Physiological energetics of brooding in Chilean oyster Ostrea chilensis. Mar Ecol Prog Ser 171:151-163

> Chaparro OR, Thompson RJ, Ward JE (1993) In vivo observations of larval brooding in the Chilean oyster, Ostrea chilensis Philippi, 1845. Biol Bull 185:365-372

> Chaparro OR, Cubillos VM, Montiel YA, Paschke KA, Pechenik JA (2008a) Embryonic encapsulation and maternal incubation: requirements for survival of the early stages of the estuarine gastropod Crepipatella dilatata. J Exp Mar Biol Ecol 365:38-45

- Chaparro OR, Montiel YA, Segura CJ, Cubillos VM, Thompson RJ, Navarro JM (2008b) The effect of salinity on clearance rate in the suspension-feeding estuarine gastropod Crepipatella dilatata under natural and controlled conditions. Estuar Coast Shelf Sci 76:861-868

Chaparro OR, Segura CJ, Montiel YA, Thompson RJ, Navarro JM (2008c) Variations in the quantity and composition of seston from an estuary in southern Chile on different temporal scales. Estuar Coast Shelf Sci 76:845-860

Chapman PM, Farrell MA, Brinkhurst RO (1982) Relative tolerances of selected aquatic oligochaetes to individual pollutants and environmental factors. Aquat Toxicol 2:47-67

Clutton-Brock TH (1991) The evolution of parental care. In: Krebs J, Clutton-Brock TH (ed) Monographs in behavior and ecology. Princeton University Press, Princeton, NJ

Collin R (2003) Worldwide patterns in mode of development in calyptraeid gastropods. Mar Ecol Prog Ser 247:103-122

Collin R, Chaparro OR, Winkler F, Véliz D (2007) Molecular phylogenetic and embryological evidence that feeding larvae have been reacquired in a marine gastropod. Biol Bull 212:83-92

Djangmah JS, Shumway SE, Davenport J (1979) Effects of fluctuating salinity on the behaviour of the West African blood clam Anadara senilis and on the osmotic pressure and ionic concentrations of the haemolymph. Mar Biol 50: 209-213

> Fernández M, Bock C, Pörtner HO (2000) The cost of being a caring mother: the ignored factor in the reproduction of marine invertebrates. Ecol Lett 3:487-494

Fretter V (1984) Prosobranchs. In: Tompa AS, Verdink NH, van den Biggelaar JAM (eds) The Mollusca, Vol 7. Reproduction. Academic Press, Orlando, FL

Gallardo CS (1979) Especies gemelas del género Crepidula (Gastropoda, Calyptraeidae) en la costa de Chile: una redescripción de $C$. dilatata Lamarck y descripción de $C$. fecunda n. sp. Stud Neotrop Fauna Environ 14:215-226

Gallardo CS (1987) Estrategias reproductivas en invertebrados marinos bentonicos, con especial referencia a moluscos; un enfoque global del problema y sus perspectivas. In: Mems II Congreso Latinoamericano sobre Ciencias del Mar. Instituto del mar del Perú, Lima, p 381-389

Gallardo CS (1993) Reproductive habits and life cycle of the small clam Kingiella chilenica (Bivalvia: Cyamiidae) in an estuarine sand flat from the South of Chile. Mar Biol 115: 595-603

Gillespie JM, McClintock JB (2007) Brooding in echinoderms: How can modern experimental techniques add to our historical perspective? J Exp Mar Biol Ecol 342:191-201

> Grant A (1983) On the evolution of brood protection in marine benthic invertebrates. Am Nat 122:549-555

> Hand SC, Stickle WB (1977) Effects of tidal fluctuations of salinity on pericardial fluid composition of the American oyster Crassostrea virginica. Mar Biol 42:259-271

- Harris JO, Maguire GB, Edwards S, Hindrum SM (1998) Effect of ammonia on the growth rate and oxygen consumption of juvenile greenlip abalone, Haliotis laevigata Donovan. Aquaculture 160:259-271

Hutchinson S, Hawkins LE (1992) Quantification of the physiological responses of the European flat oyster Ostrea edulis L. to temperature and salinity. J Molluscan Stud 58: 215-226

> Kim WS, Huh HT, Huh SH, Lee TW (2001) Effects of salinity on endogenous rhythm of the Manila clam, Ruditapes philippinarum (Bivalvia: Veneridae). Mar Biol 138: $157-162$

Kinne O (1966) Physiological aspects of animal life in estuaries with special reference to salinity. Neth J Sea Res $3: 222-244$

Kinne O (1971) Salinity. In: Kinne O (ed) Marine ecology, Vol 1. Wiley, Chichester, p 683-1244

Mackie GL, Qadri SU, Clarke AH (1974) Development of brood sacs in Musculium securis Bivalvia: Sphaeriidae. Nautilus 88:109-111

Maeda-Martínez AN (1987) The rates of calcium deposition in shells of molluscan larvae. Comp Biochem Physiol A 86: $21-28$

- Marsden ID (2004) Effects of reduced salinity and seston availability on growth of the New Zealand little-neck clam Austrovenus stutchburyi. Mar Ecol Prog Ser 266:157-171

Monteiro NM, Almada VC, Vieira MN (2005) Implications of different brood pouch structures in syngnathid reproduction. J Mar Biol Assoc UK 85:1235-1241

Montory JA, Chaparro OR, Cubillos VM, Pechenik JA (2009) Isolation of incubation chambers during brooding: effect of reduced $\mathrm{pH}$ on protoconch development in the estuarine gastropod Crepipatella dilatata (Calyptraeidae). Mar Ecol Prog Ser 374:157-166

> Morritt D, Spicer JI (1996) Developmental ecophysiology of the beachflea Orchestia gammarellus (Pallas) (Crustacea: Amphipoda). I. Female control of the embryonic environment. J Exp Mar Biol Ecol 207:191-203 
Morton B (1977) The occurrence of inflammatory granulomas in the ctenidial marsupium of Corbicula fluminea (Mollusca: Bivalvia): a consequence of larval incubation. J Invertebr Pathol 30:5-14

Navarro JM (1988) The effects of salinity on the physiological ecology of Choromytilus chorus (Molina, 1782) (Bivalvia: Mytilidae). J Exp Mar Biol Ecol 122:19-33

Navarro JM, Gonzalez CM (1998) Physiological responses of the Chilean scallop Argopecten purpuratus to decreasing salinities. Aquaculture 167:315-327

Pechenik JA (1978) Adaptations to intertidal development: studies on Nassarius obsoletus. Biol Bull 154:282-291

Pechenik JA (1979) Role of encapsulation in invertebrate life histories. Am Nat 114:859-870

Pechenik JA (1982) Ability of some gastropod egg capsules to protect against low-salinity stress. J Exp Mar Biol Ecol 63:195-208

Pechenik JA (1983) Egg capsules of Nucella lapillus (L.) protect against low-salinity stress. J Exp Mar Biol Ecol 71: 165-179

Pechenik JA (2006) Larval experience and latent effects metamorphosis is not a new beginning. Integr Comp Biol 46:323-333

Pennington JT, Hadfield MG (1989) A simple nontoxic method for the decalcification of living invertebrate larvae. J Exp Mar Biol Ecol 130:1-7

Purchon RD (1968) The biology of the Mollusca. Pergamon Press, Oxford

Rawlings TA (1999) Adaptations to physical stresses in the intertidal zone: the egg capsules of neogastropod molluscs. Am Zool 39:230-243

Raymond JF, Himmelman JH, Guderley HE (2004) Sex differences in biochemical composition, energy content and allocation to reproductive effort in the brooding sea star Leptasterias polaris. Mar Ecol Prog Ser 283:179-190

Rumrill SS (1990) Natural mortality of marine invertebrate larvae. Ophelia 32:163-198

Shumway SE (1977) The effect of fluctuating salinity on the tissue water content of eight species of bivalve molluscs. J Comp Physiol 116:269-285

Solorzano L (1969) Determination of ammonia in natural waters by the phenolhypochlorite method. Limnol Oceanogr 14:799-801

Spicer JI, Strömberg JO (2003) Metabolic responses to low

Editorial responsibility: Inna Sokolova,

Charlotte, North Carolina, USA salinity of the shipworm Teredo navalis (L.). Sarsia 88: 302-305

Surbida KL, Wright JC (2001) Embryo tolerance and maternal control of the marsupial environment in Armadillidium vulgare (Isopoda: Oniscidea). Physiol Biochem Zool 74: 894-906

$>$ Taborsky B, Foerster K (2004) Female mouthbrooders adjust incubation duration to perceived risk of predation. Anim Behav 68:1275-1281

Tankersley RA, Dimock RV (1992) Quantitative analysis of the structure and function of the marsupial gills of the freshwater mussel Anodonta cataracta. Biol Bull 182:145-154

Tankersley RA, Wieber MG (2000) Physiological responses of postlarval and juvenile blue crabs Callinectes sapidus to hypoxia and anoxia. Mar Ecol Prog Ser 194:179-191

Thorson G (1946) Reproduction and larval development of Danish marine bottom invertebrates, with special reference to planktonic larvae in the Sound Oresund. Medd Kom Dan Fisk-Havunders Plankton 4:1-523

> Thorson G (1950) Reproductive and larval ecology of marine bottom invertebrates. Biol Rev Camb Philos Soc 25:1-45

Toro JE, Chaparro OR (1990) Conocimiento biológico de Ostrea chilensis Philippi, 1845. Impacto y perspectivas en el desarrollo de la ostricultura en Chile. In: Hernandez A (ed) Cultivo de moluscos en América Latina. CIID/ CANADA, Editora Guadalupe, Bogotá, p 231-264

Toro JE, Winter JE (1983) Estudios en la ostricultura Quempillen, un estuario del sur de Chile. Parte I. La determinación de los factores abióticos y la cuantificación del seston como oferta alimenticia y su utilización por Ostrea chilensis. Mems Asoc Latinoam Acuicult 5:129-144

Underwood AJ (1997) Experiments in ecology. Their logical design and interpretation using analysis of variance, 1st edn. Cambridge University Press, Sydney

Videla JA, Chaparro OR, Thompson RJ, Concha II (1998) Role of biochemical energy reserves in the metamorphosis and early juvenile development of the oyster Ostrea chilensis. Mar Biol 132:635-640

Wilson JA, Chaparro OR, Thompson RJ (1996) The importance of broodstock nutrition on the viability of larvae and spat in the Chilean oyster Ostrea chilensis. Aquaculture 139:63-75

Wood EM (1974) Development and morphology of the glochidium larva of Anodonta cygnea (Mollusca: Bivalvia). J Zool 173:1-13

Submitted: June 18, 2008; Accepted: October 13, 2008 Proofs received from author(s): December 23, 2008 